\title{
The Diabetes and Allergies
}

Eduardo José Caldeira*

"Corresponding author: Eduardo José Caldeira, Chief - Department of Morphology and Basic Pathology Faculty of Medicine of Jundiaí, Jundiaí, São Paulo, Brazil, Tel: +551145871095; E-mail: drdcaldeira@gmail.com

Received date: October 07, 2015; Accepted date: December 07, 2015; Published date: December 14, 2015

Copyright: @ 2015 Caldeira EJ. This is an open-access article distributed under the terms of the Creative Commons Attribution License, which permits unrestricted use, distribution, and reproduction in any medium, provided the original author and source are credited.

\section{Editorial}

The type I diabetes is related to different factors, the main one being the autoimmune factor. This autoimmunity behaves as an allergic response. The autoimmune attack on the pancreatic cells may have a physiological sequence, similar to allergic processes. The insulin resistance can be triggered by the use of food and is related to cellular inflammation. This fact is very common in type II diabetes. However, this insulin resistance and inflammatory processes before related to this type of diabetes can now also be described in cases of diabetes type I. This information may eventually open new perspectives for the study of diabetes, as well as for understanding the different processes involving the allergies. 